\title{
THE POSITION OF INDIRECT EVIDENCE AS VERIFICATION TOOLS IN THE CARTEL CASE
}

\author{
Veri Antoni* \\ Business Law Department, Faculty of Law Universitas Gadjah Mada, Yogyakarta \\ 1st Sosio Justicia St., Bulaksumur, Sleman, D.I. Yogyakarta 55281
}

\begin{abstract}
Indirect (circumstantial) evidence, either economic evidence or communication evidence, has been used in cartel cases in many countries such as United States of America, Japan, Australia, Brazil, Malaysia, and others. According to Indonesia criminal procedure law, the position of indirect (circumstantial) evidence is categorized as an indication (clue evidence) whereas according to Indonesia civil procedure law, indirect (circumstantial) evidence is categorized as presumption. Considering the characteristics the antimonopoly law which aims to find material truth, the position of indirect evidence is more properly said to be an indication. Owing to its status as an indication, indirect evidence should be exhibited together with the other direct evidence.
\end{abstract}

Keywords: evidences, indirect (circumstantial) evidence, cartel.

\section{Intisari}

Indirect evidence atau bukti tidak langsung, baik bukti ekonomi atau bukti komunikasi, telah digunakan dalam kasus-kasus kartel di banyak negara, seperti Amerika Serikat, Jepang, Australia, Brazil, Malaysia, dan lain-lain. Menurut hukum acara pidana Indonesia, posisi bukti tidak langsung dikategorikan sebagai indikasi (bukti petunjuk), padahal menurut hukum acara perdata Indonesia, bukti tidak langsung dikategorikan sebagai praduga. Mengingat karakteristik hukum anti-monopoli yang bertujuan untuk mencari kebenaran materiil, posisi bukti tidak langsung lebih tepat dikatakan indikasi. Karena statusnya sebagai indikasi, bukti tidak langsung harus dipamerkan bersama dengan bukti langsung lainnya.

Kata kunci: bukti tidak langsung, pembuktian, kartel.

\section{Pokok Muatan}

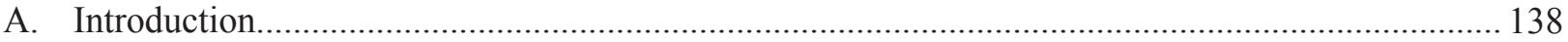

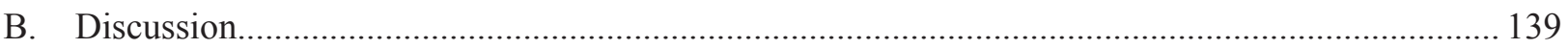

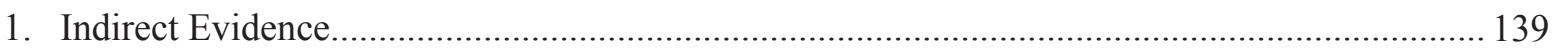

2. The Position of Indirect Evidence in the Cartel Case in Many Countries...................................... 140

3. The position of Indirect Evidence in Criminal Procedure Indonesia.......................................... 144

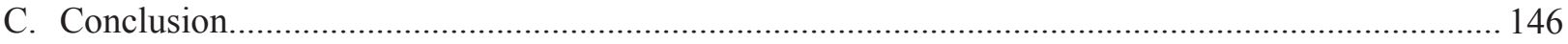




\section{A. Introduction}

The business competition law is known since March 5th, 1999 in Indonesia, since the enactment of Law No. 5 of 1999 on Prohibition of Monopoly Practice and Imperfect Trade Competition (hereinafter the Law No. 5 of 1999) and declared valid a year later. No more than a decade, the Law No. 5 of 1999 has given many lessons that can be learned by entrepreneur, society (consumers, business world, KPPU ${ }^{1}$ (The Commission of Business Competition) and the judiciary institution. ${ }^{2}$ Some successes have been seen, for example many cases have been decided by the Commission. Even some of the decisions become benchmark especially in terms of determining the winner of the tender related to the APBN (State Budget). ${ }^{3}$

However, it isn't also infrequently the decisions of the Commission (KPPU) which cause controversy that make a long debate in the society. Among them is a decision which related to the notion of cartel violation, for example in the telecommunications sector related to SMS cartel, in the consumption goods sector (cooking oil cartel), transportation sector (the notion cartel of fuel surcharge), and the last is cement cartel.

Cartel is very important and phenomenal in the application of business competition law in many countries. Cartel included as big violation in business competition law because it causes social welfare reduction, that is reputed real enough. ${ }^{4}$ Cartel is one of the agreement which is mostly happens in monopolization. Simply, cartel is defined as an agreement from one business operator with his business competitor to break of the competition between them. ${ }^{5}$ Article 11 of the Law No. 5 of 1999 states that business operator is prohibited making an agreement with his business competitor which is intended to influence the price by means adjusting the production and or marketing of goods and services that can cause the monopolization and or imperfect competition. ${ }^{6}$

In practice, it is difficult to prove that there is alleged of cartel violation. Most of the authority of business competitions in many countries is very careful to prove the cartel. Various circumstances are often considered as an indicator of cartel that have a little difference in fact with the situation where fair competition takes place. For example, about parallel indication of prices (price parallelism) is often regarded as an action that done together collusively to determine the price (price fixing) by the members of the cartel. ${ }^{7}$

Furthermore, the use of economic indications which are called circumstantial evidence or indirect evidence, (hereinafter indirect evidence) as the evidence of the violation of the cartel, still be debate. For example, the KPPU Decision No. 24/ KPPU-I/2009, dated May 4th, 2010 related to the 18 alleged of cooking oil business that make cartel action, then it is canceled by the District Court of Central Jakarta by District Court Verdict No. 03/ KPPU.JKT.PST, because Commission (KPPU) use indirect evidence as the only evidence. ${ }^{8}$

Meanwhile, in many countries the existence of indirect evidence in the enforcement of competition law especially for some cartel cases have been accepted. Brazil, in The Steel Cartel Case for example, even though admit the existence of economic evidence, the CADE decision is not only based on the consideration of economic evidence, but also

\footnotetext{
CICODS FH UGM, 2009, Hukum Persaingan Usaha di Indonesia dan Perkembangannya, CICODS FH UGM, Yogyakarta, p. 1. Ningrum Natasya Sirait dalam Ibid., p. 37.

Ibid.

KPPU, "Sulitnya Membuktikan Praktik Kartel", http://www.kppu.go.id/id/sulitnya-membuktikan-praktik-kartel/, accessed at 4 August, 2011. Tommi Ricky Rosandy, "Kartel dalam Hukum Persaingan Usaha", http://tommirrosandy.wordpress.com/2011/03/26/kartel-dalam-hukumpersaingan-usaha/, accessed on 4 August 2010.

Compared with Black's Law Dictionary, as quoted by Tommy Ricky Rosandy, cartel meant “A combination of producer of any product joined together to control its productions its productions, sale and price, so as to obtain a monopoly and restrict competition in any particular industry or commodity". See at Ibid. KPPU, "Sulitnya Membuktikan Praktik Kartel", Loc.cit.

The case begins from the existence of 18 presuppositions of cooking oil company do cartel agreement. This cartel presupposition related to the decrease of crude palm oil that don't go along with the decrease of cooking oil price for inland consumers. Related to that matter, the Commission judge the 18 companies, and based on the Commission Verdict No. 24/KPPU-I/2009 to pay the fines as much as 299 billion rupiah. The evidence used by the Commission is indirect evidence, and then canceled by PN central Jakarta, because the banding done by the reporter. The cassation reason of the Commission verdict by PN because the indirect evidence can't be used as the only evidence, although cross share ownership by Temasek Holdings Pte., Ltd. in Telkomsel dan Indosat, indirect evidence is used. See in Bataviase, "Tuduhan Kartel Minyak Goreng Dibatalkan", http://bataviase.co.id/node/580075, accessed on 4 August 42011.
} 
based on what they known as "parallelism plus theory". ${ }^{9}$ In Malaysia, the use of indirect evidence cannot stand alone, it must be supported by another evidence. ${ }^{10}$ However, Czech Republic, in the Concerted Practice of Bakery Producers case that uses indirect evidence as the only evidence. ${ }^{11}$ Based on the explanation above, this article is meant to investigate how the position of indirect evidence in the business competition law in many countries, especially in cartel case and how the position of indirect evidence in Indonesian procedural law considering that it isn't mentioned or explained in the Law No. 5 of 1999.

\section{B. Discussion \\ 1. Indirect Evidence}

Bummulen and Moeljatno gave an evidence or proven that give an assurance which is appropriate and thinkable (redelijk) about: (a) whether a certain thing really happen; and (b) what the cause. ${ }^{12}$ The purpose of gave evidence is to give assurance to the judge about certain event. As a result, the thing which is proven is the event not the law. For proven activity the evidence is needed. Thus, the evidence is material that is used for proving a case. ${ }^{13}$

In the civil law procedure, evidence are written evidence, witness evidence, presupposition, admission, the oath, the local investigation, and expert statement. ${ }^{14}$ Presupposition evidence, admission and the oath are categorized as indirect evidence that isn't presented physically but it was got as the conclusion from case or the event which happen in the court session. ${ }^{15}$ In this context, the indirect evidence means that presupposition is very relevant to be presented. Article 1915 of the Civil Code states that presupposition is the conclusion in which by the Law or judges that concluded from the clear event to another event that still unclear. HIR (Herzien Inlandsch Reglement) is not explained what is meant by presupposition, but it only suggests if the presupposition is allowed to be noticed as the evidence, that is: if the presupposition is not based on certain law ${ }^{16}$ that is only allowed to be noticed by the judges when he determines his decision, only if the presupposition is important, accurate, certain, and related from one to another. ${ }^{17}$

Meanwhile, in the evidence of Civil Law Procedure are witness explanation, expert statement, document, guideline, and accused explanation. In this context, the indirect evidence means that presupposition is very relevant to be presented. Based on Article 181 paragraph (1) Criminal Procedure Code (the Code of Criminal Law Procedure), guideline is defined as an action, event or condition because of its adjustment with one to another or with the criminal act itself, determine that it has occurred a criminal act and who the actor. The guideline can be gained only from the witness explanation, document, and accused explanation. ${ }^{18}$

In the context of cartel case, OECD (Organization for Economic Cooperation and Development) divides evidence into two kinds, that is: direct evidence, such as documents, the attachment is included, oral or written agreement related to the participation in the cartel and indirect evidence or circumstance evidence. Indirect evidence consists of communication evidence and economic evidence. In the OECD report stated, "one is evidence that cartel operators met or otherwise communicated, but does not describe the substances of their communication. It might be called "communication' evidence for purpose of this discussion". Included in communication evidence that are: record calls or conversation among the competitors (but

Edgard Antonio Pereira, "Using Time Series Analysis to Understand Price Setting”, http://laep.univ-paris1.fr/SEPIO/SEPIO111122Pereira. $p d f$, accessed on 4 August 2012.

10 A. Pitlo (translated by M. Isa Arief), 1978, Pembuktian dan Daluwarsa, Menurut Kitab Undang-Undang Hukum Perdata Belanda, Intermasa, Jakarta, p. 26

Sudikno Mertokusumo, 2002, Hukum Acara Perdata di Indonesia, Liberty, Yogyakarta, p. 129.

Yahya Harahap, 2004, Hukum Acara Perdata tentang Gugatan, Persidangan, Penyitaan, Pembuktian, dan Putusan Pengadilan, Sinar Grafika, Jakarta, p. 558.

Sudikno Mertokusumo, 1998, Hukum Acara Perdata Indonesia, Liberty, Yogyakarta, p. 171

Article 184 of Criminal Code.

Eddy O.S. Hiariej, 2012, Teori dan Hukum Pembuktian, Erlangga, Jakarta, pp. 109-110.

H. Goksin Kakevi, et al., "Can Economics Help Us with Cartel Detection”, Paper, Lisbon, Portugal, October 28th, 2008, p. 1.

Ibid.

Ibid. 
not substantial), travel together in tourist attraction, or participate in meeting, for example in the trading conference.

Besides that, document or official report related to the prices, the presence of demand and capacity, internal document evidence, or strategy to determine competitor price. Related to economic evidence is mentioned, "economic evidence identifies primarily firm conduct that suggest that agreement was reached, but conduct of the industry as a whole, element market structure which suggest that secret price fixing was feasible, and certain practices that can be used to sustain a cartel agreement". The things which are included in economic evidence are parallel pricing, high profit which is not normal, stable market section, the history of violation of competition law, and market structure. Economic evidence related to market structure for example: concentration level, low concentration against the market, a high level of market entry, high vertical integration and standardization or equalization of the products.

\section{The Position of Indirect Evidence in the Cartel Case in Many Countries}

The cartel case is a very difficult case to prove. Cartel is different from other types of anticompetitive violations laws like misapplication the dominant position and vertical barrier where the doer or related companies obviously appear. On the other hand in the cartel case, practices and the responsibility among the actor is a secret. Because, the violator is generally only one part that holds the information that is needed in the detection process and penalization. That is why in the pursuit of the cartel case it usually gives requisite for special action which is different from requisite for detecting and investigating another violation of business competition law. ${ }^{19}$

The authority of business competition in many countries is usually trying to get direct evidence like agreement in sue of the cartel cases, but it is most likely the direct evident is not provided. ${ }^{20}$
The actors of the cartel in reality hide their activity and they don't want to cooperate along with the investigators toward their action that have been done by them, unless they see the opportunity for being participate in leniency programme. ${ }^{21}$ Therefore, in this context the existence of evidence become very important. ${ }^{22}$

Nowadays, in the cartel case the existence of indirect evidence has been accepted in many countries, for example:

\section{a. Brazil}

In Brazil, steel cartel (The Steel Cartel Case) is one of the cases where the CADE (Council for Economic Defence) concludes that the guilty parties because of collude based on indirect evidence. In that case CADE does not find direct evidence that the guilty parties have been coordinated to increase the price. Therefore, $\mathrm{CADE}$ in doing the investigation based on the economic evidence. CADE states explicitly that "it was possible to condemn a cartel based on exclusively on economic evidence, if all the other possible rational explanations for the practice were excluded". However, it is needed to be understood that in this case CADE not only considerate the existence of economic evidence. CADE state that the doer is blamed based on "the parallelism plus" theory, that is "the first issue taken into account was the fact that the price increase of the companies, at similar rate and dates, could not be explained just by referring to it as oligopoly's interdependence". ${ }^{23}$

Although CADE does not consider the meeting as a direct evidence of collusion, but CADE state that thing is strong indication that there is previous meeting between companies before they meet with the government (SEAE). According to CADE, indirect evidence indicates that the steel companies have been reached the agreement related to the increasing the price when they consult SEAE. Based on that matter the committee determines the fine based on the law as much as USD 48 million. ${ }^{24}$

\section{b. Czech Republic}

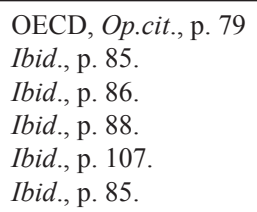


In Czech Republic, Concerted Practice of Bakery Producer is a sample case where the decision of The Authority of the Business Competition is only based on indirect evidence. ${ }^{25}$ In this case direct evidence like agreement for collusion, the testimony positive of witness is not enough, so the Authority of the Business Competition of the Czech Republic use indirect evidence. The forms of the indirect evidence are correspondence (mostly via email) between the competitors when it is presented (found) when the authority conducting the rummage suddenly. The existence acts of anti-competitive between corruptor. For example, an email A which is written by the Director of A Company sent to the Director of B Company continued to the Director of C Company. The content of the email is price analysis from the prime buyer (supermarket), and general strategy toward the buyer. In addition, the other evidence is premise by the listed company in the official report of the meeting of the executive managers of a company that states that the price information from company $B$ is not presented at today meeting, but will be communicated to the company by the competitor in the next meeting. ${ }^{26}$ Based on that, the Authority of Business Competition concludes that the prohibited practicing in the market has been done, declare its decision, and determine the fines as much as CZK 120 million, and prohibit the doer to do the violation in the future. ${ }^{27}$

\section{c. Japan}

One of the cases in Japan which relate to the use of indirect evidence in Japan is Bid Riggs case in tender which is done by the U.S. Air Transport. ${ }^{28}$ In this case, relevant product is operation service and the maintenance of the communication facility. The companies have been colluded with one another to design the winner of the tender that is done by U.S. Air Transport. Same with CADE in Brasilia and the Authority of Czech Republic Business Competition, JFTC (Japan Fair Trade Commission) also can't find the direct evidence to show the concrete and explicit agreement of bid rigging. The existence of fundamental agreement is needed to show the trade barrier that shouldn't have been. ${ }^{29}$

Related to that case, the Tokyo High Court judges that the agreement of bid rigging can be shown with indirect facts. As for indirect evidence is found are: First, the establishment of Kabuto $C l u b$. The purpose of the club establishment should be clarified whether to raise the personal relationship between companies or to do anti-competition practice. Second, some meetings of Kabuto Club. Kabuto Club members do the meeting before joining the auction process. In every meeting, companies insist that every participant want to be the winner of the tender. The company which has declared its will to be the winner arranges another participants' tender document.

Interestingly, if there is a non-member participant that wins the tender, the average of the contract will decrease until $40 \%$. According to that fact, The Tokyo High Court judges that the establishment of Kabuto Club shows that there is a collusion agreement. Although Kabuto Club has a function to increase the personal relationship between the company worker but it cannot eliminate the existence of the closed collusive agreement. Although the collusive agreement doesn't have concrete rule which organizes which company will win the tender, that matter isn't meant that the agreement doesn't include in unreasonable restraint of trade. ${ }^{30}$

The breaker companies have carefully tried to not leave the evidence about the cartel agreement (for example minutes of meeting). Therefore, it is needed a verification uses indirect evidence. Although leniency system has been acquainted in Japan since January 2006, determination of fact based on indirect evidence still needed. Although after applying the leniency program, JFTC still investigate based on indirect evidence (without leniency application). In the case where JFTC accept the leniency application, JFTC need to evaluate the 
credibility from the company statements that join that program. ${ }^{31}$

\section{d. USA}

Some big cases in USA are always use indirect evidence to prove the commitment consciously to do the same pattern on the purpose of anti-competition. If the entrepreneur only relies on direct evidence in the form of admission or written agreement then that matter can decrease the ability of the competition institute to prove the collusion which breaks the law. Thus, indirect evidence can be used if it is economically possible.

Some cases in USA judge that indirect evidence is not enough to prove the collusion for example Baby Food Blomkest Fertilizer, dan Williamson Oil. Interestingly, there are some cases that admit the indirect evidence. They are High Fructose Corn Syrup case that prove the collusion simply by using indirect evidence. ${ }^{32}$ Furthermore, how the use of indirect evidence in many countries can be seen in the table below:

Table 1. The Use of Indirect Evidence as the Evidence in Cartel Case in Many Countries

\begin{tabular}{|c|c|c|c|c|}
\hline No. & Country & Case & Type of Indirect Evidence & Description \\
\hline 1. & Argentina & Cement Cartel & $\begin{array}{l}\text { CNDC (Commission for the Defence } \\
\text { of Competition) combines between } \\
\text { indirect evidence, economic evi- } \\
\text { dence, and facilitating practice (rea- } \\
\text { sonable information exchange) used } \\
\text { by broke company to witness. }\end{array}$ & \\
\hline \multirow[t]{2}{*}{2.} & Brazil. & $\begin{array}{l}\text { The Rio de } \\
\text { Janeiro - Sao } \\
\text { Polo Air Line } \\
\text { Case }\end{array}$ & $\begin{array}{l}\text { - The price parallelism } \\
\text { - Meeting of the company leaders } \\
\text { - The tool for coordinating prices }\end{array}$ & \\
\hline & & $\begin{array}{l}\text { The Newspaper } \\
\text { Cartel Case }\end{array}$ & $\begin{array}{l}\text { - The existence of parallel coopera- } \\
\text { tion price } \\
\text { - There are some infor-mation to the } \\
\text { reader about their increasing price } \\
\text { and the same con-tent. }\end{array}$ & \\
\hline 3. & Chili & $\begin{array}{l}\text { The Fresh Milk } \\
\text { Case }\end{array}$ & $\begin{array}{l}\text { Conduct evidence (marketing distri- } \\
\text { bution, purchase refusal, cost distribu- } \\
\text { tion) }\end{array}$ & \\
\hline 4. & $\begin{array}{l}\text { Czech } \\
\text { Republik }\end{array}$ & $\begin{array}{l}\text { Concerted } \\
\text { Practice of Bak- } \\
\text { ery Product }\end{array}$ & $\begin{array}{l}\text { - Hand-written notes; } \\
\text { - Correspondence and busy email } \\
\text { among competitor } \\
\text { - Business note or negotiation } \\
\text { - The witness from unrelated witness } \\
\text { in cartel } \\
\text { - Telephone log } \\
\text { - Journey note }\end{array}$ & $\begin{array}{l}\text { The authority decision } \\
\text { based only indirect evi- } \\
\text { dence }\end{array}$ \\
\hline 5. & Latvia & $\begin{array}{l}\text { Latvia-Hen } \\
\text { Eggs }\end{array}$ & $\begin{array}{l}\text { - There are executive meeting about } \\
\text { determining price in two meeting } \\
\text { - Economic evidence (the existence } \\
\text { of the egg increased price after } \\
\text { meeting of company executive) }\end{array}$ & \\
\hline 6. & $\begin{array}{l}\text { Europe } \\
\text { cimmittee }\end{array}$ & $\begin{array}{l}\text { Limburges Vinyl } \\
\text { Maatschappij } \\
\text { NV and others } \\
\text { vs. Commission }\end{array}$ & & $\begin{array}{l}\text { The use of indirect evi- } \\
\text { dence-in adding the } \\
\text { direct evidence-have } \\
\text { become something that } \\
\text { is very needed }\end{array}$ \\
\hline
\end{tabular}

31 Safinaz Mohammad Hussein, the speaker of the University Kebangsaan Malaysia in the National Seminar "Unfair Competition in Cyber Space: Comparative Perspectives from Indonesia Malaysia”, Speech, Malang, 15 May 2012.

32 Riris Munadiya, "Bukti Tidak Langsung (Indirect Evidence) dalam Penanganan Kasus Persaingan Usaha", Jurnal Persaingan Usaha, Edisi 5 - Tahun 2011, p. 177. 
If see in the table above that almost every country nowadays admit the existence of indirect evidence to upright the business competition law especially for cartel cases. It can be a question whether indirect evidence can stand alone as evidence or should be supported by other evidence? Answering this question there is a little variation among various countries.

Brazil in case of The Steel Cartel Case for example, although admit the existence of economic evidence, but the CADE's decision not only based on economic evidence consideration but also based on what is known as "parallelism plus theory".33 In Malaysia, the use of indirect evidence can't stand alone, it should be supported by other evidences.34 In Australia, to determine the existence of agreement (meeting of the mind) that should be proven the existence of the agreement that break the competition law, circumstances evidence can be used. This evidence can be guideline of parallel action, guideline of team work, the existence of collusion, the direction structure of same price (in the case of price fixing). Yet, the matter still needs direct evidence. Thus, if indirect evidence is used its position only as the supporter or lasing from one of the meant evidence. ${ }^{35}$

In contrast to Brazil and Malaysia, Czech Republic, in the case of Concerted Practice of Bakery Producers using indirect evidence as the only evidence. While the United States, in the case of High Fructose Corn Syrup which prove conspiracy only by using indirect evidence, whereas in the case of Baby Food, Blomkest Fertilizer, and Williamson Oil direct evidence deemed insufficient to prove the existence of the conspiracy.

Furthermore, Business and Industry Advisory Committee to the OECD Global Forum on Competition in the Discussion of Point Summary states that, "BIAC understand indirect evidence that may be used in cartel analysis, but submits that it is imperative that such evidence only be used where there is also direct evidence of an agreement". It also said that, "Other types of evidence are relevant communication, but sometimes they are ambiguous. Economic evidence, such as parallel pricing, is more ambiguous, and it should not be sufficient by itself in a cartel case". Then specifically for the European Union stated that,

The Commission has acknowledged that the use of indirect evidence in European investigations becomes how indispensable, as direct evidence from investigators becomes increasingly elusive' grasp. With the changing character of international cartels, which now are well aware of the antitrust risks posed by their activities and so take increasingly sophisticated means to avoid leaving a paper trail, the Commission now relies on a combination. Generally the direct and indirect evidence of in it is antitrust decisions.

Although there are differences in the various countries, but generally in many countries tend to use indirect evidence must be supported by other evidence, for example, direct evidence. It will be important, particularly, for indirect evidence in the form of economic evidence, consider the economic approach of the legal theory. Economic approach relies on models and assumption, even create different results. While the law material, or any assumption of the model is not allowed because the sought is the truth that material. In addition, judges and lawyers have limited knowledge about the economic evidence.

In the context of competition law itself, it associated with evidence of economic experts, such as, Neven, Freeman, Patocky, stated that the economic evidence is not absolute character, nevertheless can be used if it comes from the deep logical assumption and used properly so the fact is relevant. Laws are often faced with technical (medical and patent law), so that competition of law can also be faced with the same thing. Competition of law is different from other legal techniques which are in economy branches. ${ }^{36}$

There are economic limits to competition of law. Judge Brayer stated in dissent of Leegin Decision in 2007 that the law does not like the economy,

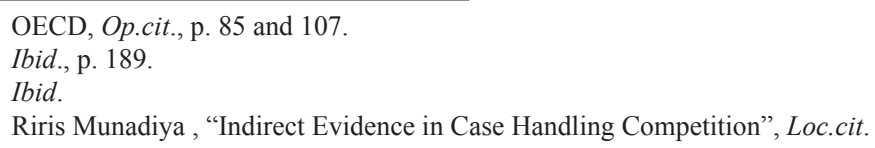


is an administrative system. The law has the effect through judges and lawyers who provide advice to the client, where the competition law should be actual administrative. Antitrust law cannot and should not completely mimic the economic outlook. The view of economic restrictions in competition law is together with other experts. They identify the challenges for law enforcement to be able to adapt to the analysis techniques accurately that is different with the behavior of pro- competition against administrative rules. The administrative rules regarded as stable and predictable as a business that can be run.

However, based on experience of the United States and the European Union, the courts have accepted and even require the use of economic and economic evidence in competition cases, although the court does not always find a convince of economic evidence. Currently many cases in the United States indicates that cartel behavior can be proved by using indirect evidence. Although there is no direct evidence of the agreement, competition agencies can support the proof elements by using evidence of a conscious adjustment (conscious parallelism). When there are fewer competitors in highly concentrated markets that have the same price of pattern, it can be used as potential evidence for understanding between competitors in adjusting prices. However, the evidence in the court, the parallel evidence shall be equipped with an additional factor that indicate the behavior is conscious and not a decision independently of entrepreneurs. This factor may include evidence that show that the entrepreneurs take positions that are contrary to their economic interests, and have the motivation to do the cartels. ${ }^{37}$

\section{The position of Indirect Evidence in Crim- inal Procedure Indonesia}

Business competition law has its own procedural law as regulated on the Law No. 5 of 1999, the Commission Decision No. 1 of 2010 on Procedures for Case Management, Supreme Court Regulation No. 3 of 2010 on Procedures for Filing Objections against the decision of Commission. But in some cases there are legislation that exists in law is not enough. For example, it is not clear if these rules are inadequate can be used in procedural law based on the Criminal Procedure Code. The Criminal Procedure Code referred inspection functions are not known in the Civil Procedure Code .

In addition there are some anomalies in the Indonesian business competition of laws because of the different legal traditions. Indonesian business competition of law (Law No. 5 of 1999) is substantially closer to the tradition of Anglo-Saxon state of law, while Indonesia is a country with continental European legal tradition. Therefore, there are anomalies in the Indonesian business competition of laws, as a result of the law state diffuse Anglo-Saxon tradition with Continental Europe. On the one hand, the event resembles civil law, but on the other hand, the event resembles the criminal procedural law set out in the Criminal Code, for example: ${ }^{38}$

1. It was submitted to the Commission is a report, not a lawsuit.

2. Although there is no report, the Commission may conduct an examination of business actors. It suggests that violations of the Law No. 5 of 1999 "is not a crime on complaint".

3. Evidence examination of the Commission set forth in Article 42 of the Law No. 5 of 1999 is similar to Article 184 of Criminal Procedure Code.

4. The decision of the Commission which are not adhered by businesses that violate the Law No. 5 of 1999 has a "degree" as a result of the investigation in the criminal case .

The term of indirect evidence is unknown to the Law No. 5 of 1999, Article 42 of the Law No. 5 of 1999 relating to evidence states that, "The tools of commission evidence in the form of: witness tes-

\footnotetext{
Ibid.

38 Bambang Winarno, "Juridical Analysis on the Law No. 5 of 1999 on Prohibition of Monopolistic Practices and Unfair Business Competition", Papers, National Seminar "Unfair Competition in Cyber Space: Comparative Perspectives from Indonesia Malaysia”, in Malang, May 15, 2012, p. 9.
} 
timony, expert testimony, letter and or documents, instructions, and information entrepreneurs". Based on Article 42 of the Law No. 5 of 1999, when juxtaposed with the regulation of Section 184 of Criminal Procedure Code states that, "Tool is valid evidence: witness testimony, expert testimony, letters, instructions, and the testimony of the defendant", it appears that there is no evidence of a difference in the criminal procedure law of business competition event, unless the term "testimony of the defendant" in the law of general criminal procedure, but in the business competition of law called "information entrepreneurs".

Then if reference to the regulation of Article 48 paragraph (1) of the Law No. 5 of 1999 that the violation of Article 11 -related to cartelcan be subject to fine of criminal penalty as low Rp25.000.000.000,- (twenty five billion rupiah) and a maximum of Rp100.000.000.000,- (one hundred billion rupiah), or imprisonment for a replacement in all the time 6 (six) months. Therefore, a violation of the act punishable by criminal sanctions must be proven by the common law of criminal procedure.

In addition, the nature of competition law is not a formal correctness, but material, i.e. beyond a reasonable doubt, as well as criminal law. In the context of beyond a reasonable doubt, the decision states that the defendant is guilty, a judge must be convinced (without a reasonable doubt) that the defendant is guilty of the alleged for crime. Here, the prosecutor must prove the reasonable doubt to the judge and that makes sense about the defendant's guilt. ${ }^{39}$ That is, in the context of business competition law, in the search for material truth, the necessary confidence -in this case the Commission- that the businessmen do or do not do anything that causes monopolistic practices or unfair competition. ${ }^{40}$

Based on the above, if then analogize the procedural of business competition law with, it is among the five existing evidence in the criminal procedure law, so the indirect evidence in the category "hint". Article 181 paragraph (1) of Crimi- nal Procedure Code, the instructions are defined as actions, events or circumstances, which is due to the correspondence, both from each other as well as with the criminal act itself, indicates that a crime has occurred and who was responsible. These instructions can only be obtained from witness testimony, letters, and testimony of the defendant. ${ }^{41}$

Assessment of the strength evidence of the instruction in any situation done by the judge wisely and prudent after an inspection with full accuracy and togetherness based on his conscience. The terms of the instructions as evidence must have the concurrence of each other for the actions that occurred. Moreover, the circumstances relating to each other with crimes and based on judges' observations obtained from witness statements, letters, or the testimony of the defendant. ${ }^{42}$ Thus, if interpreted by a contrario, so the tool of the existence will be if there is other evidence, from witness statements, letters, or the testimony of the defendant. In the law of evidence, the instructions are supplementary evidence or evidence accessories. That is, the instructions are not independent evidence, is secondary evidence derived from primary evidence in this case is the witness testimony, letters, and testimony of the defendant.

In addition, it associated with minimum bewijs, i.e. the minimum evidence required in proof to tie the independence of judges. In the context of criminal procedural law in Indonesia, to convict the defendant, there must be at least two items of evidence added with the judge's conviction. It means that in order to convict, the minimum bewijs are two items of evidence. Basing on the analogy above, the use of indirect evidence in competition law -which in this case included in the evidence, it concluded in instructions - cannot stand alone. The use of indirect evidence must be supported other evidence.

Furthermore, when viewed in the context of civil proceedings, the existence of indirect evidence, in the scope of presupposition evidence. Because, no direct evidence can be found in the cartel

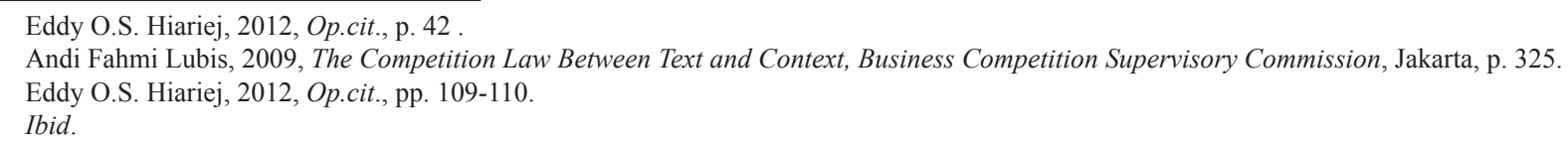


as a written agreement and witnesses, the evidence that can be used is presupposition. There are two kinds of prejudice is prejudice espoused by the fact (judge) and laws presupposition. The difference between them lies in who conclude a conclusion from these events: whether the judge based on the facts of the events corresponding to each other or by law.

The economic situation can be observed as a result of price collusion among businesses that indicated the cartel offense may be included in the category of indirect evidence in the form of presupposition. It can be categorized as a presupposition based on the fact (feitelijke, rechterlijke vermoedens, or paesumptiones facti). The judge here that may determine whether and to what extent likely to prove a particular event by proving other events. ${ }^{43}$ Economic evidence and communication proof, and facilities into a tool to prove the occurrence of indicative of cartel event made by businesses. To realize the existence presupposition must be evidence or other legal facts, thus it can be said that the allegation as evidence assesoir (complementary) to the direct written evidence or witnesses. Presupposition cannot stand alone without relying on paper evidence or witnesses.

Therefore, consider to the Law No. 5 of 1999 does not provide a clear position on indirect evidence, if it is then returned to the general procedural law, the law of civil procedure and criminal procedure law, so the indirect evidence can be considered as evidence in the criminal procedure code

\section{BIBLIOGRAPHY}

\section{A. Books}

CICODS FH UGM, 2009, Hukum Persaingan Usaha di Indonesia dan Perkembangannya, CICODS FH UGM, Yogyakarta.

Harahap, Yahya, 2004, Hukum Acara Perdata tentang Gugatan, Persidangan, Penyitaan, Pembuktian, dan Putusan Pengadilan, Sinar Grafika, Jakarta.

Hiariej, Eddy O.S., 2012, Teori dan Hukum Pembuktian, Erlangga, Jakarta. or presupposition evidence in law civil procedure. Neither evidence nor evidence instructions are supplementary evidence (assesoir), which cannot stand alone. Thus, in the context of Indonesian business competition law, especially cartel cases, whether using indirect evidence as evidence, it must be accompanied by other evidence. The use of indirect

\section{Conclusion}

Based on these descriptions above we can conclude the following: First, indirect evidence, either in the form of communication evidence and economic evidence, in the context of business competition of law, in particular cartel case, has been accepted in many countries as one type of evidence. Proving indirectly (indirect evidence) is one way to enhance the existence of direct evidence. Communication evidence or facilitation is more important than the economic evidence. Second, in the context of procedural law, both criminal procedural law or civil law, indirect evidence can be considered as evidence in the criminal procedure code or presupposition evidence in civil law proceedings. Neither the instructions nor the supplementary evidence is complementary evidence (assesoir) which cannot stand alone. At the time, consider the characteristics that the sought in competition law is material truth, then the position of indirect evidence precisely in the category of evidence. As instructions evidence, then its position cannot stand alone, but must be equipped with tools other direct evidence. evidence cannot stand alone.

Lubis, Andi Fahmi, 2009, The Competition Law Between Text and Context, Business Competition Supervisory Commission, Jakarta.

Mertokusumo, Sudikno, 1998, Hukum Acara Perdata Indonesia, Liberty, Yogyakarta. 2002, Hukum Acara Perdata di Indonesia, Liberty, Yogyakarta.

Pitlo, A. (translated by M. Isa Arief), 1978, Pembuktian dan Daluwarsa, Menurut Kitab Undang-Undang Hukum Perdata Belanda, 
Intermasa, Jakarta.

\section{B. Journal}

Munadiya, Riris, "Bukti Tidak Langsung (Indirect Evidence) dalam Penanganan Kasus Persaingan Usaha", Jurnal Persaingan Usaha, Komisi Pengawas Persaingan Usaha, Edisi 5, Tahun 2011.

\section{Paper, Speech}

Hussein, Safinaz Mohammad, National Seminar "Unfair Competition in Cyber Space: Comparative Perspectives from Indonesia Malaysia”, Speech, Malang, 15 May 2012.

Kakevi, H. Goksin, et al., "Can Economics Help Us with Cartel Detection", Paper, Lisbon, Portugal, October 28th, 2008.

Winarno, Bambang, "Juridical Analysis on Law No. 5 of 1999 on Prohibition of Monopolistic Practices and Unfair Business Competition", Papers, National Seminar "Unfair Competition in Cyber Space: Comparative Perspectives from Indonesia Malaysia", Paper, in Malang, May 15, 2012.

\section{Internet Articles}

Bataviase, "Tuduhan Kartel Minyak Goreng Dibatalkan", http://bataviase.co.id/ node/580075, accessed August 4th, 2011.

KPPU, "Sulitnya Membuktikan Praktik Kartel", http://www.kppu.go.id/id/sulitnya-membuktikan-praktik-kartel/, accessed at 4 August, 2011.

Meliala, Melita Kristin, "Suspicions-suspicions", http://melitakristinmeliala.blogspot. com/2010/10/persangkaan-persangkaan. html, accessed May 26, 2012.

Pereira, Edgard Antonio, "Using Time Series Analysis to Understand Price Setting", http://laep. univ-paris1.fr/SEPIO/SEPIO111122Pereira. $p d f$, accessed August 4th, 2012.

Rosandy, Tommi Ricky, "Kartel dalam Hukum Persaingan Usaha", http://tommirrosandy.wordpress.com $/ 2011 / 03 / 26 /$ kartel-dalam-hukumpersaingan-usaha/, accessed at 4 August, 2010.

\section{E. Legislation}

Criminal Code. 